University of Nebraska - Lincoln

DigitalCommons@University of Nebraska - Lincoln

Drought Mitigation Center Faculty Publications Drought - National Drought Mitigation Center

$1-7-2019$

\title{
Socioecological Determinants of Drought Impacts and Coping Strategies for Ranching Operations in the Great Plains
}

Tonya Haigh

University of Nebraska-Lincoln, thaigh2@unl.edu

Walter H. Schacht

University of Nebraska - Lincoln, wschacht1@unl.edu

Cody L. Knutson

University of Nebraska - Lincoln, cknutson1@unl.edu

Alexander J. Smart

South Dakota State University

Jerry Volesky

University of Nebraska-Lincoln, jvolesky1@unl.edu

See next page for additional authors

Follow this and additional works at: https://digitalcommons.unl.edu/droughtfacpub

Part of the Climate Commons, Environmental Indicators and Impact Assessment Commons, Environmental Monitoring Commons, Hydrology Commons, Other Earth Sciences Commons, and the Water Resource Management Commons

Haigh, Tonya; Schacht, Walter H.; Knutson, Cody L.; Smart, Alexander J.; Volesky, Jerry; Allen, Craig R.; Hayes, Michael; and Burbach, Mark E., "Socioecological Determinants of Drought Impacts and Coping Strategies for Ranching Operations in the Great Plains" (2019). Drought Mitigation Center Faculty Publications. 139.

https://digitalcommons.unl.edu/droughtfacpub/139

This Article is brought to you for free and open access by the Drought -- National Drought Mitigation Center at DigitalCommons@University of Nebraska - Lincoln. It has been accepted for inclusion in Drought Mitigation Center Faculty Publications by an authorized administrator of DigitalCommons@University of Nebraska - Lincoln. 


\section{Authors}

Tonya Haigh, Walter H. Schacht, Cody L. Knutson, Alexander J. Smart, Jerry Volesky, Craig R. Allen, Michael Hayes, and Mark E. Burbach 


\title{
Socioecological Determinants of Drought Impacts and Coping Strategies for Ranching Operations in the Great Plains ${ }^{\text {is }}$
}

\author{
Tonya R. Haigh ${ }^{\mathrm{a}, *}$, Walt Schacht ${ }^{\mathrm{b}}$, Cody L. Knutson ${ }^{\mathrm{c}}$, Alexander J. Smart ${ }^{\text {d, }}$, Jerry Volesky ${ }^{\mathrm{e}}$, Craig Allen ${ }^{\mathrm{f}}$, \\ Michael Hayes ${ }^{g}$, Mark Burbach ${ }^{\text {h }}$ \\ a Rural Sociologist, National Drought Mitigation Center, University of Nebraska, Lincoln, NE 68583-0988, USA \\ b Professor, Department of Agronomy and Horticulture, University of Nebraska, Lincoln, NE 68583-0915, USA \\ c Research Professor, National Drought Mitigation Center, University of Nebraska, Lincoln, NE 68583-0988, USA \\ d Professor, Department of Natural Resource Management, South Dakota State University, Brookings, SD 57007, USA \\ e Range and Forage Specialist, West Central Research and Extension Center, University of Nebraska - Lincoln, North Platte, NE 69101, USA \\ ${ }^{\mathrm{f}}$ Leader and Professor, US Geological Survey - Nebraska Cooperative Fish and Wildlife Research Unit, School of Natural Resources, University of Nebraska, Lincoln, NE 68583-0984, USA \\ g Professor, School of Natural Resources, University of Nebraska, Lincoln, NE 68583-0988, USA \\ ${ }^{\text {h }}$ Geoscientist, Conservation and Survey Division, School of Natural Resources, University of Nebraska, Lincoln, NE 68583-0995, USA
}

\section{A R T I C L E I N F O}

\section{Article history:}

Received 18 December 2017

Received in revised form 18 October 2018

Accepted 7 January 2019

\section{Key Words:}

adaptive capacity

rangeland

resilience

sensitivity

vulnerability

\begin{abstract}
A B S T R A C T
In Great Plains rangelands, drought is a recurring disturbance. Ranchers in this region expect to encounter drought but may not be adequately prepared for it. Efforts to encourage drought preparedness would benefit from a better understanding of the conditions under which managers make decisions to minimize the impacts of drought. We tested the direct and moderating roles of the drought hazard and the social-ecological context on drought impacts and response. This study was conducted with ranchers in western and central South Dakota and Nebraska following the drought that began in 2012. We surveyed ranchers regarding the effects of the drought and their responses and used multimodel analysis to explore the relationships among measures of drought preparedness, drought response, and drought impacts. Drought severity was the primary predictor of all impacts, but specific types of impacts were varied depending on the operation's enterprise mix, resources, and management. The socioecological characteristics of the ranch system predicted drought response actions taken, by either providing the necessary resources and capacity to take action or creating sensitivity in the system that required action to be taken. We conclude with recommendations for learning from current drought experiences in order to better adapt to future drought events.
\end{abstract}

(C) 2019 The Society for Range Management. Published by Elsevier Inc. All rights reserved.

\section{Introduction}

Rangeland managers in the US Great Plains have a long history of coping with and managing drought and its impacts. Recent studies have found evidence that ranchers are adopting more proactive approaches to drought management and, following recent droughts, consider themselves better prepared for drought than they had been in the past (Coppock, 2011; Kachergis et al., 2014). At the same time, despite their preparation for drought and increased flexibility, ranchers report

it This work was supported by the USDA Natural Resources Conservation Service through a Conservation Innovation Grant (69-3A75-13-90) and University of Nebraska Lincoln's Agricultural Research Division Strategic Funding program. One coauthor is affiliated with the Nebraska Cooperative Fish and Wildlife Research Unit, which is jointly supported by a cooperative agreement between the US Geological Survey, Nebraska Game and Parks Commission, University of Nebraska - Lincoln, US Fish and Wildlife Service, and Wildlife Management Institute.

* Correspondence: Tonya R. Haigh, National Drought Mitigation Center, University of Nebraska-Lincoln, 802 Hardin Hall, Lincoln, NE 68583-0988, USA.

E-mail address: thaigh2@unl.edu (T.R. Haigh). experiencing more severe impacts than they expected during drought (Kachergis et al., 2014). These results lead us to wonder if current expectations of drought preparedness are adequate to meet the challenge of future droughts.

The goal of ranch drought management is to minimize the risk associated specifically with climate variability (Thurow and Taylor, 1999). But drought management goals, as well as expectations of what constitutes an impact, may differ from one production system to another and from one time period to another. Drought management takes place in the context of multifaceted, dynamic, adaptive socioecological systems that encompass rangeland ecosystems, livestock production, markets, and business and family systems (Folke et al., 2002; Walker and Abel, 2002; Dunn et al., 2005; Walker et al., 2012). The management of these interconnected systems is driven by the manager's unique objectives for each, and each management decision is likely to lead to tradeoffs in system dynamics, making drought management more complex than it might appear (Birge, 2017). Adding to the uncertainty of drought management, interactions among socioecological systems may result in unexpected outcomes during drought, and variations in 
the severity and length of drought events may result in impacts that differ even within the same ecological system and management domain (Wilhite, 2000). All of these factors make it difficult to isolate cause and effect relationships in drought management or to predict effective strategies for future droughts. In this paper, we take a quantitative, theory-driven approach to exploring the interactions and causal relationships among the characteristics of the socioecological system, the severity of the drought, the management or response actions taken during the drought, and the resulting impacts to forage feed capacity, rangeland health, animal productivity, and financial health. The analysis informs recommendations for improving rangeland managers' preparedness for future drought events.

We frame our investigation in two bodies of literature that have emerged from the study of natural systems management and climate stressors such as drought. Climate vulnerability theory provides a useful model in which a system's exposure to a hazard, sensitivity to harm, and capacity to adapt can be measured to predict the system's vulnerability to hazards such as climate change (Yohe and Tol, 2002; Brooks, 2003; Adger et al., 2004; Eakin and Bojórquez-Tapia, 2008). The use of sensitivity and adaptive capacity in vulnerability theory are related to concepts used in socioecological resilience theory to describe a system's ability to absorb disturbance, self-organize, and adapt (Walker and Abel, 2002). Resilience theory is uniquely valuable, though, in providing frameworks for understanding systems with multiple potential stable states and the nonlinear changes that may occur in a system in response to a disturbance such as drought (Carpenter et al., 2001; Miller et al., 2010). A conceptual framework by Chapin et al. (2009) links resilience and vulnerability as complementary theoretical approaches to understanding change. In the model, interactions between socioecological systems' resources and management define what happens when an external driver (e.g., drought) affects a system. The model draws direct paths of influence among the socioecological system, its sensitivity to harm, impacts, and the learning, coping, or adaptive processes that emerge as a result of impacts (Fig. 1).

A drought management framework informed by this model allows managers, researchers, and advisors to more effectively examine the effects of their predrought management and resources on the response options they are likely to use and the impacts they experience, as well as to learn and plan to adapt their systems for future drought events. In order to specify the model in the context of rangeland drought management, we evaluate the model's core theoretical pathways, as well as alternative causal pathways, using a survey of individual ranch operations following a recent drought event. Specifically, we explore the effect of the system's resources and management characteristics on impacts managers experienced and the response actions they took, at distinct drought severity levels. We also propose that grouping coping actions conceptually with learning, innovating, and adapting may conceal potential feedback relationships between actions and impacts, and explore alternative models that predict causal relationships from coping action to impact (e.g., Feola and Binder, 2010). Our research questions include the following:

1. To what degree does the socioecological system predict drought impacts under various drought severity scenarios by defining the system's sensitivity to harm?

2. To what degree does the socioecological system predict rangeland manager's drought responses under various drought severity scenarios by defining a) the sensitivity of the system (i.e., the need to take action), and/or b) the adaptive capacity of the system?

3. Is the nature of the relationship between range managers' drought response actions and impacts unidirectional from one variable to the other, or reciprocal?

\section{Methods and Descriptive Summary of Variables}

Our study focuses on range-based livestock producers in western and central South Dakota and Nebraska. The study area is part of the US Great Plains region, dominated by grasslands, row crops, and small grains agriculture. The area is semiarid, with average annual precipitation ranging from 381 to $610 \mathrm{~mm}$ (USDA NRCS, 2006).

The study focuses on the drought event beginning in 2012. That year was the third warmest on record for the continental United States (NOAA-NCEI, 2012) and the driest on record for portions of Nebraska and South Dakota. These conditions caused stress for farmers and ranchers across the Midwest and Great Plains and caught many off guard because they had experienced above-normal precipitation during the previous several years. Regions of Nebraska and South Dakota rangelands experienced moderate to exceptional drought through 2013 and into 2014, but in general, 2012 was the most severe (Fig. 2). Rangeland managers across Nebraska and South Dakota experienced different drought severities and lengths. Generally, the drought lasted longer and was more extreme in Nebraska and less so in South Dakota, providing an opportunity to examine managers' experiences under differing drought scenarios.

We conducted a survey in fall 2014 to assess rangeland managers' perspectives on the effects of the drought on their rangeland and livestock operations. The survey instrument was developed by a team of scientists with expertise in the areas of rangeland ecology, ranch

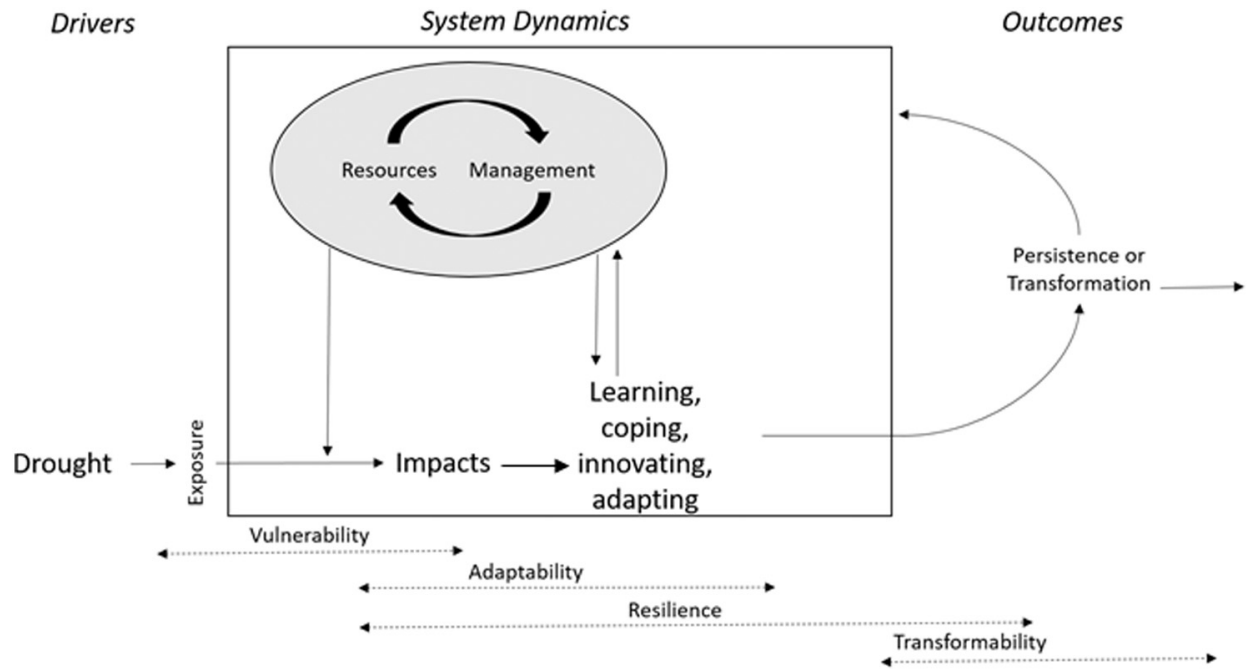

Figure 1. Conceptual framework linking processes leading to vulnerability, resilience, and transformation, proposed by Chapin et al. (2009). 

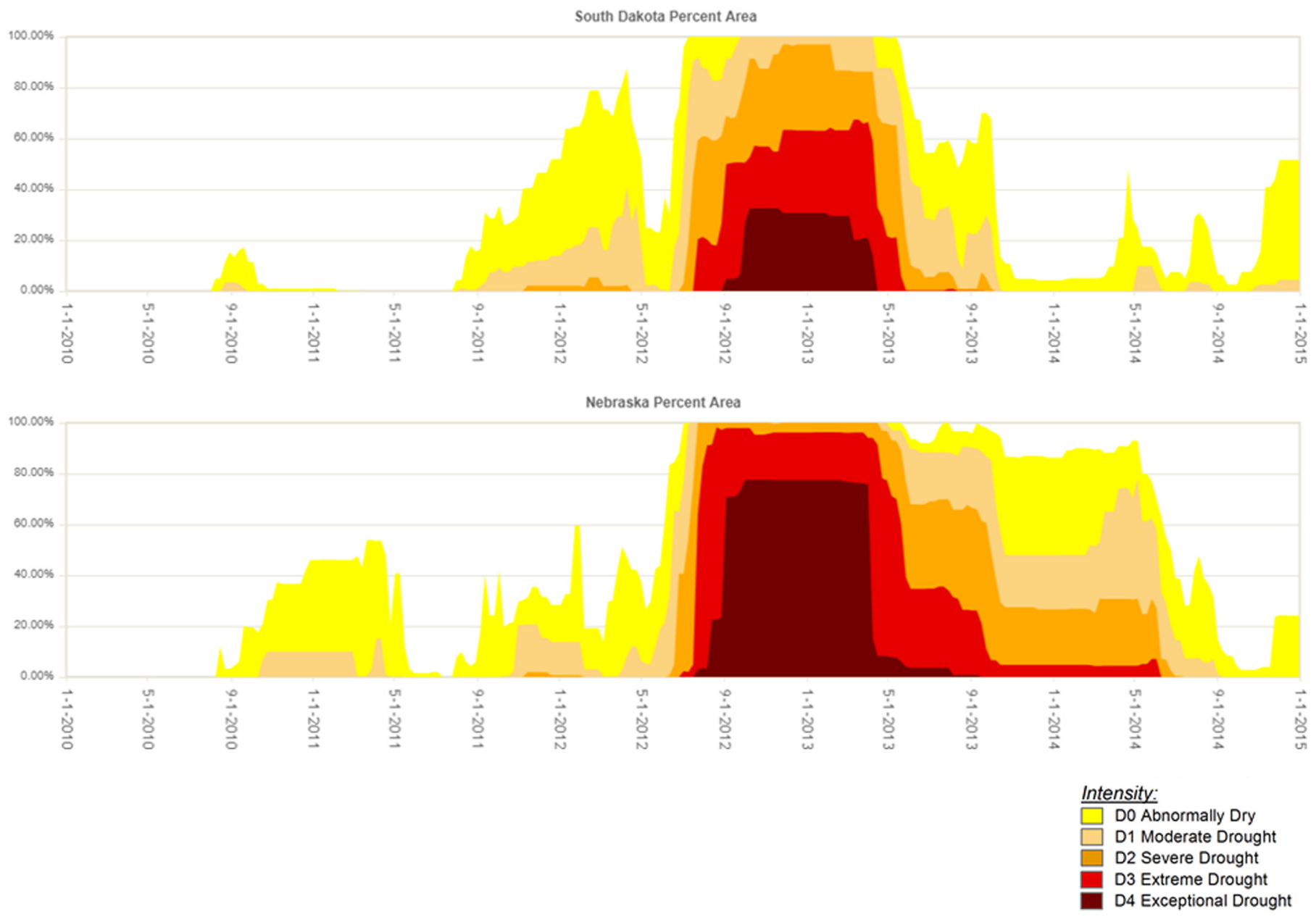

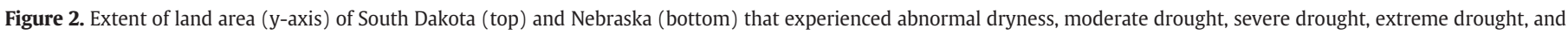
exceptional drought between January 2010 and January 2015 (x-axis) (U.S. Drought Monitor, droughtmonitor.unl.edu).

management and economics, sociology, and drought mitigation. The questions covered the 2012 to 2014 period and included items about ranch operations and resources, drought harm to resources, and drought management actions taken during the period. The survey was administered by the US Department of Agriculture (USDA) - National Agriculture Statistics Service (NASS) regional office based in Lincoln, Nebraska. The sampling unit for the survey was individual producers who were identified as the operation's primary decision maker, excluding grazing associations, with at least 40 ha of permanent pasture and/ or rangeland and at least 25 head of cattle. A systematic probabilitybased sample was drawn from a sorted list of counties found in the western two-thirds of South Dakota and Nebraska and then from a distribution of ranch sizes, to ensure geographic and size representation. We sampled 500 operations in South Dakota and 500 operations in Nebraska. The survey was administered by mail in October 2014, and follow-up phone calls were made in early November 2014 to nonresponders, which resulted in a $42 \%$ response rate. The survey sample included individuals who had participated in the 2012 NASS Census, enabling researchers to match records and to include NASS Census variables describing the operations and managers in the study. Not all of the survey respondents had completed the 2012 NASS Census, resulting in smaller sample sizes for analyses that include these variables.

\section{Measures of the Socioecological System}

Our analysis included survey-based measurements of socioecological characteristics that have been highlighted in prior research as affecting drought response and impacts, such as size of ranch operation in land base (hectares of pasture and range) (Bastian et al., 2006; Kachergis et al., 2014), ecological composition of rangeland, and irrigation availability (Wilhelmi and Wilhite, 2002) (Table 1). Because the number of cattle was measured via NASS Census at the end of 2012, potentially confounding results, we do not include it in predictive models but include the variable in correlation tables. The analysis also included variables linked with providing operational flexibility and buffers to the system (e.g., enterprise mix, type of feed base, reserve forage capacity, percent of total household income from the farming/ranching operation, grazing strategies) (Thurow and Taylor, 1999; Dunn et al., 2005; Briske et al., 2008; Stockton and Dhoubhadel, 2011; Haigh and Knutson, 2013; Knutson and Haigh, 2013; Kachergis et al., 2014). Use of the Pasture, Rangeland, Forage (PRF) Insurance Program, which was launched in 2007 for South Dakota and in 2009 for Nebraska, was included in the analysis as a management approach to risk transfer that may affect drought response and impacts (Vandeveer et al., 2013).

\section{Measure of Drought Severity}

To measure drought severity, we used the median Standardized Precipitation Evapotranspiration Index (SPEI) value calculated monthly for each county represented in the survey sample. The SPEI accounts for both precipitation and potential evapotranspiration. Values of -1.00 to -1.49 correspond to "moderately dry," -1.5 to -1.99 to "very dry," and -2.00 and below to "extremely dry." SPEI values calculated at a 3-month time step have been shown to represent the general response time of forage production to drought (Svoboda and Fuchs, 2016). Historical drought data were downloaded from the National 
Table 1

Characteristics of the ranch organization used in analysis to predict drought impacts and response.

\begin{tabular}{|c|c|c|c|}
\hline Variable, question wording & Code & Source & Descriptive statistics \\
\hline $\begin{array}{l}\text { Pasture hectares } \\
\text { Report number of hectares managed in permanent } \\
\text { pasture and rangeland, woodland pasture, } \\
\text { and other pasture and grazing land. }\end{array}$ & $\begin{array}{l}=\text { Total number of hectares of permanent } \\
\text { pasture, range, woodland, and cropland } \\
\text { used for pasture }\end{array}$ & 2012 Census (NASS) & $\begin{array}{l}\text { Mean }=1046 \text { ha (SD } 1285) \\
\text { (range 0-7 } 824 \text { ha) }(n=284)\end{array}$ \\
\hline $\begin{array}{l}\text { Number of cattle and calves } \\
\text { Report number of beef cows, heifers, steers, } \\
\text { calves, and bulls as of } 31 \text { December, } 2012\end{array}$ & $\begin{array}{l}=\text { Beef cow inventory }+ \text { other cattle } \\
\text { (heifers, steers, calves, and bulls) inventory }\end{array}$ & 2012 Census (NASS) & $\begin{array}{l}\text { Mean }=349(\text { SD 571) } \\
(\text { range 0-7544) }(n=361)\end{array}$ \\
\hline $\begin{array}{l}\text { Percent of income from operation } \\
\text { In } 2012 \text {, what percent of the principal operator's } \\
\text { total household income came from this operation? }\end{array}$ & Self-reported percent (0-100\%) & 2012 Census (NASS) & $\begin{array}{l}\text { Mean }=62 \%(\text { SD 36\%) } \\
(\text { range } 0-100 \%)(n=367)\end{array}$ \\
\hline $\begin{array}{l}\text { Enterprise } \\
\text { How would you describe your cattle operation? } \\
\text { (select all that apply) }\end{array}$ & $1=$ yes $; 0=$ no & 2014 survey & $\begin{array}{l}- \text { Cow/calf-94\% } \\
\text { - Stocker/feeder-40\% } \\
\text { - Hay/forage production to sell-16\% } \\
\text { - Custom grazing } \\
\text { (cattle run on ranch but not owned)-13\% } \\
\text { - Feedlot-9\% } \\
\text { - Registered seed stock-6\% } \\
\text { - Dairy-1\% } \\
(n=417)\end{array}$ \\
\hline $\begin{array}{l}\text { Ecological description of pastures/range } \\
\text { How would you describe the majority of your } \\
\text { pastures or rangeland? (Check one.) }\end{array}$ & & 2014 survey & $\begin{array}{l}- \text { Native tall grass- } 8 \% \\
\text { - Native mixed grass-57\% } \\
\text { - Native short grass-14\% } \\
\text { - Mixture of native and } \\
\text { introduced grasses-20\% } \\
\text { - Seeded introduced grasses-0\% } \\
(n=407)\end{array}$ \\
\hline $\begin{array}{l}\text { Access to irrigation } \\
\text { Do you manage any irrigated crop/hay land } \\
\text { or subirrigated meadows? }\end{array}$ & $1=$ yes $; 0=$ no & 2014 survey & $36 \%$ yes $(n=416)$ \\
\hline $\begin{array}{l}\text { Feed resources } \\
\text { Grazing operations vary in their range and } \\
\text { winter feed base. What type of feed base } \\
\text { do you have? (Select all that apply.) }\end{array}$ & $1=$ yes; $0=$ no & 2014 survey & $\begin{array}{l}\text { - Range/pasture and hay land-79\% } \\
\text { - Corn stalks or other crop residue-54\% } \\
\text { - Range/pasture, no hay land-23\% } \\
\text { - Purchased hay-41\% } \\
\text { - Purchased feed/dry lot-36\% } \\
\text { - Cover crops-18\% } \\
(n=414)\end{array}$ \\
\hline $\begin{array}{l}\text { Reserve forage capacity } \\
\text { In a nondrought year, do you normally use } \\
\text { all of your forage feed capacity (pasture, } \\
\text { hay, crop residue, etc.) or do you keep } \\
\text { some in reserve? (Check one.) }\end{array}$ & $\begin{array}{l}1=\text { yes "I tend to keep some of my } \\
\text { forage capacity in reserve" } \\
0=\text { no "I tend to use all of my forage } \\
\text { capacity annually" } \\
\text { Left out of analysis-"I don't know," } \\
\text { "Not applicable" }\end{array}$ & 2014 survey & $\begin{array}{l}\text { - I tend to use all of my forage } \\
\text { capacity-15\% } \\
\text { - I tend to keep some of my forage } \\
\text { capacity in reserve- } 80 \% \\
\text { - I don't know-2\% } \\
\text { - Not applicable-3\% } \\
(n=407)\end{array}$ \\
\hline $\begin{array}{l}\text { Grazing system }{ }^{1} \\
\text { Please tell us whether you currently } \\
\text { use the following practices: }\end{array}$ & $1=$ yes, $0=$ no & 2014 survey & $\begin{array}{l}\text { - Season-long continuous-32\% } \\
\text { - Intensive early stocking-19\% } \\
\text { - Rest rotation-58\% } \\
\text { - Deferred rotation-22\% } \\
\text { - Intensively managed-15\% } \\
\text { ( } n \text { for each question }=401 \text {, } \\
396,400,397,396, \text { respectively) }\end{array}$ \\
\hline $\begin{array}{l}\text { Use of Pasture, Rangeland, Forage Insurance (PRF) } \\
\text { Did you participate in the PRF } \\
\text { program between } 2012 \text { and } 2014 ?\end{array}$ & $1=$ yes, $0=$ no & 2014 survey & $32 \%$ yes $(n=395)$ \\
\hline
\end{tabular}

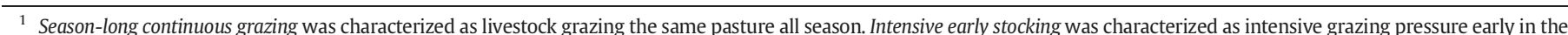

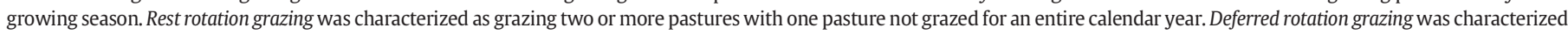

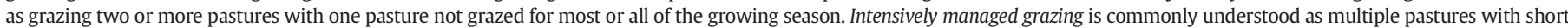

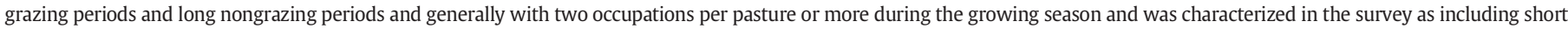
duration, management-intensive grazing, and mob grazing.

Drought Mitigation Center's Drought Risk Atlas (NDMC, 2017), a station-based atlas of drought indices, and interpolated using inverse distance weighting to compute county-level weighted averages. To compare the levels of drought severity experienced by range managers, we aggregated monthly SPEI values between April and September of each year and used the median value as a measure of central tendency. Therefore, the values do not represent the most extreme drought months but rather the median drought severity for the year. We focused on 2012 drought severity values because the severity of the drought eased in 2013 and 2014 and did not add to the fit of the models. Note that in the "Results" section later (Tables 3 and 4), we report the inverse of the SPEI value, such that higher positive values represent more severe drought, to ease interpretation of the data.

\section{Measures of Impacts}

The analysis included five survey-based measures of drought impacts: impact to forage feed capacity, rangeland health, animal production, cash flow, and value of the ranch operation. Forage feed capacity loss was measured as the reported percentage reduction in forage feed capacity as a result of the drought, categorized as $1=$ "none," 2 $="<25 \%$," $3=$ " $26-50 \%$," $4=$ " $51-75 \%$," and $5=$ "76\% or more." Severity of drought impact on rangeland health was measured on a selfreported ordinal scale of "drought's effect on rangeland health" ranging from extremely harmful (5) to no effect (2) or beneficial (1). In the survey, rangeland health was left to the respondents' self-definition. Severity of drought impact on animal productivity, cash flow, and the 
value of the ranch operation were also measured on a self-reported ordinal scale ranging from extremely harmful (5) to no effect (2) or beneficial (1).

\section{Measures of Management Action}

The analysis included a preselected list of possible drought response actions, including supplemental feeding, grazing pastures earlier than usual, grazing cover crops or residues, moving animals to feedlot, sending custom grazed animals home early, leasing or purchasing additional grazing land, early weaning, selling culls earlier than usual, and reducing stockers and/or breeding animals. Each action was coded as $1=$ "yes, took that action that year during the drought" or $0=$ "no, did not take that action that year," for 2012, 2013, and 2014.

\section{Hypothesized Relationships}

We tested multiple alternative models that may predict the impact of drought and the manager's response actions, informed by the Chapin et al. (2009) theoretical model (see Fig. 1). For each impact, models included direct effects of drought severity and characteristics of the socioecological system, as well as potential moderation or interaction effects between drought severity and socioecological characteristics. For each coping or management action, as well, we tested alternative models that included drought severity, socioecological characteristics, and interactions between drought severity and system characteristics. Interaction effects would indicate that either the effect of drought depends on the presence or absence of a system characteristic or the effect of a characteristic may only be noticeable at more or less extreme severities of drought. Finally, we undertook an exploratory examination of the correlation between impact and management actions and the relationships that might be implied.

\section{Statistical Analysis}

We used Spearman rank (rho), a nonparametric measure of rank correlation commonly used with nominal and ordinal data, as well as data that do not follow normal distribution patterns, to identify correlations among all dependent and independent variables. Significance was determined with a $95 \%$ confidence level or an alpha $=0.05$. We used a multimodel selection process to determine the best-fitting models for predicting drought impacts and management actions. The approach identifies theory-driven models that provide the best and most parsimonious fit to describe the relationships between the independent and dependent variables, including null models predicting that management actions and drought impacts are random. We used logistic regression analysis for the binary categorical outcomes and ordered logistic analysis for the ordinal categorical outcomes (proportional odds model) to test the probability that an individual belongs in one group rather than another (Hosmer et al., 2000). Proportional odds models do not depend on the outcome category. Rather, the results are useful for informing discussion of the general direction of response (Hosmer et al., 2000).

In the analysis, each model with parameters was compared with the null model using likelihood ratio chi square $\left(\chi^{2}\right)$ statistic and the associated $P$ value. Each model was compared with other potential models predicting the same dependent variable, using the Akaike information criterion (AIC), with the smallest values indicating best model fit and with a suite of models with an AIC difference of $<2$ considered the best-fitting models available. We reported only the best-fitting model (s) for each dependent variable. We reported the McFadden's pseudo $R^{2}$, commonly reported for logistic regression. McFadden's $R^{2}$ can be interpreted similarly to traditional $R^{2}$ measured with Ordinary Least Squares Regression, but McFadden's $R^{2}$ values will be considerably lower than traditional $R^{2}$, with values of 0.20 indicating excellent fit
(McFadden, 1974). We used Stata v. 11 for all descriptive and inferential statistical analysis (StataCorp, 2009).

\section{Results}

\section{Description of Respondents/Operations}

At the time of the survey, the average age of respondents was $60 \mathrm{yr}$, similar to the national average of $58 \mathrm{yr}$ (USDA NASS, 2012). A little over half of respondents described their rangelands as primarily native mixed grass, and the rest reported mostly a mixture of native and introduced grasses or native shortgrass. Survey respondents operated cattle grazing operations with an average of 349 owned cattle, with a range of 0 to $>7500$. Almost all (90\%) of the surveyed operations included cow-calf enterprises, but many other types of operations were represented as secondary or primary enterprises. Forty percent of respondents said they raised stockers or feeder cattle, $16 \%$ raised hay or forage to sell, $13 \%$ provided custom grazing with cattle they did not own, $9 \%$ had feedlot operations, and $6 \%$ raised registered seed stock breeding operations. See Table 1 for all descriptive statistics. The type of operation correlated with the number of cattle owned and type of feed base. See Appendix 1 (Part A) for correlations among all independent variables.

Overall, the most common resources in respondents' feed base included range/pasture and hay land, corn stalks or other crop residue, and/or purchased feed or dry lot, though there were differences among the types of operations. The type of feed base was correlated with the land base (in terms of hectares of range/pasture), number of cattle, type of operation, irrigation resources, whether or not the respondent typically keeps forage reserves, and, to some degree, the grazing system used. Among respondents, rest rotation grazing was the most common grazing system used, followed by season-long continuous grazing, deferred rotation grazing, intensive early stocking, and intensively managed grazing. Grazing strategies were correlated with land base (in terms of hectares of range/pasture), type of range/pasture grass, and to a lesser degree, with feed base.

\section{Predictors of Drought Impacts}

According to respondents, the drought was most harmful to their cash reserves, rangeland health, and animal production, and least harmful to the value of their ranch operations. The majority of operations reported losing more than $25 \%$ of their forage feed capacity (Table $2 a$ ). Drought impacts correlated with a number of independent variables, as well as with each other (Appendix 1, Part B). For each type of impact, there was a different mix of socioecological characteristics and drought severity that provided the best prediction of the impact experienced, indicating that the sensitivity of the system is defined in relation to specific impacts (Table 3). For impacts to cash flow, drought severity and characteristics of the system contributed additively to the best predictive model. But impacts to forage feed capacity, animal productivity, rangeland health, and the value of the operation were best predicted by models that included the interactions between socioecological characteristics and drought severity, indicating that drought severity led to larger impacts only under specific socioecological circumstances.

\section{Predictors of Drought Response}

In general, range managers reported taking a wide variety of actions in response to drought in 2012 (Table 2b). As the drought severity decreased over time, ranchers ceased most of the drought management actions that they began in 2012 and returned to their predrought management. The rest of our analysis focuses on actions taken in 2012 because the primary predictor of taking each action in 2013 and 2014 was whether the manager had taken that action the year before. 
Table 2

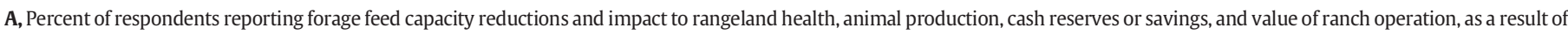
the 2012 drought. B, Percent of respondents reporting that they took each drought response action on their ranch during the drought.

\begin{tabular}{|c|c|c|c|c|c|c|}
\hline \multirow[b]{2}{*}{ A. Impacts as result of 2012 drought } & \multicolumn{6}{|c|}{ Percent reduction } \\
\hline & None & $<25 \%$ & $26-50 \%$ & $51-75 \%$ & $>75 \%$ & \\
\hline \multirow[t]{3}{*}{ Forage feed capacity reduction $(n=398)$} & $6 \%$ & $17 \%$ & $37 \%$ & $18 \%$ & $21 \%$ & \\
\hline & \multicolumn{6}{|c|}{ Impact } \\
\hline & Beneficial & No effect & Slightly harmful & Moderately harmful & Extrem & \\
\hline Harm to rangeland health $(n=414)$ & $0 \%$ & $9 \%$ & $21 \%$ & $30 \%$ & $40 \%$ & \\
\hline Harm to animal production $(n=414)$ & $1 \%$ & $12 \%$ & $21 \%$ & $30 \%$ & $36 \%$ & \\
\hline Harm to cash reserves or savings ( $n=402$ ) & $1 \%$ & $13 \%$ & $18 \%$ & $26 \%$ & $41 \%$ & \\
\hline Harm to value of ranch operation $(n=403)$ & $4 \%$ & $32 \%$ & $26 \%$ & $20 \%$ & $18 \%$ & \\
\hline \multicolumn{3}{|l|}{ B. Management actions during drought } & 2012 & 2013 & & 2014 \\
\hline \multicolumn{3}{|l|}{ Bought hay or feed to supplement $(n=415)$} & $64 \%$ & $54 \%$ & & $35 \%$ \\
\hline \multicolumn{3}{|c|}{ Fed hay from own stockpiles $(n=414)$} & $86 \%$ & $84 \%$ & & $77 \%$ \\
\hline \multicolumn{3}{|c|}{ Grazed fall or winter pastures earlier than planned $(n=413)$} & $51 \%$ & $37 \%$ & & $13 \%$ \\
\hline \multicolumn{3}{|c|}{ Grazed cover crop, crop residues, or alternative forage ( $n=412)$} & $54 \%$ & $53 \%$ & & $44 \%$ \\
\hline \multicolumn{3}{|c|}{ Moved animals to feedlot $(n=413)$} & $16 \%$ & $13 \%$ & & $8 \%$ \\
\hline \multicolumn{3}{|c|}{ Sent custom-grazed animals home early $(n=407)$} & $13 \%$ & $8 \%$ & & $4 \%$ \\
\hline \multicolumn{3}{|c|}{ Leased/rented/purchased additional land to graze $(n=412)$} & $20 \%$ & $20 \%$ & & $14 \%$ \\
\hline \multicolumn{3}{|c|}{ Weaned calves earlier than usual $(n=393)$} & $55 \%$ & $39 \%$ & & $16 \%$ \\
\hline \multicolumn{3}{|c|}{ Sold cull cows or feeder animals earlier than usual $(n=391)$} & $63 \%$ & $48 \%$ & & $21 \%$ \\
\hline \multicolumn{3}{|c|}{ Reduced breeding animal numbers $($ by $\leq 25 \%)(n=379)$} & $48 \%$ & $39 \%$ & & $19 \%$ \\
\hline \multicolumn{3}{|c|}{ Reduced breeding animal numbers (by $>25 \%)(n=357)$} & $20 \%$ & $14 \%$ & & $6 \%$ \\
\hline \multicolumn{3}{|c|}{ Reduced stocker/yearling numbers (by $\leq 25 \%)(n=329)$} & $18 \%$ & $18 \%$ & & $8 \%$ \\
\hline \multicolumn{3}{|c|}{ Reduced stocker/yearling numbers (by > 25\%) $(n=319)$} & $14 \%$ & $12 \%$ & & $7 \%$ \\
\hline
\end{tabular}

Appendix 1 (Part B) shows correlations of drought management actions with the range of independent variables, as well as with drought impacts, and with other drought actions. Table 4 lists the best predictive model for each drought management action taken in 2012. In general, the operation's feed base provided the best predictive models of the manager's actions related to supplementing the feed base (e.g., feeding hay from the manager's own stockpiles, purchasing hay or feed to supplement, and grazing crop residues or alternative forages). Drought severity did not contribute to predictive models for either feeding the manager's own hay or grazing alternative forages. The operation's grazing system predicted whether or not managers grazed fall or winter pastures earlier than planned in 2012.

The relationships between socioecological characteristics and actions that involved destocking livestock were more nuanced.
Some characteristics appeared to act as sources of capacity, increasing the likelihood of actions regardless of the drought severity. For example, those who had feedlot operations were more likely than others to send animals to a feedlot at any severity of drought. Other characteristics appeared to represent the sensitivity of the operation in predicting actions. These characteristics predicted whether or not the action would be necessary in order to cope with the drought. For example, drought severity increased the likelihood of making large reductions to stocker/ yearling numbers only for those who relied on range/pasture/hay land, notably precipitation-dependent sources of feed, in their feed base. And drought severity predicted selling cull cows earlier than usual only for those who did not typically keep reserve forage on hand or operate a custom grazing enterprise.

Table 3

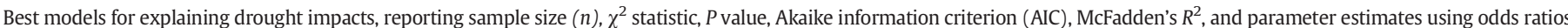
and standard error in parentheses.

\begin{tabular}{|c|c|c|c|c|c|}
\hline Drought impacts, odds ratio, and (standard error) & $n$ & $\chi^{2}$ & $P$ & AIC & McFadden's $\mathrm{R}^{2}$ \\
\hline $\begin{array}{l}\text { Reduction in forage feed capacity } \\
2012 \text { drought severity } 5.76(2.13) \\
\text { Pasture acres } 1.000(0) \\
\text { Interaction of custom grazing and drought severity } 0.06(0.07)\end{array}$ & 253 & 30.50 & $<0.01$ & 732.86 & 0.04 \\
\hline $\begin{array}{l}\text { Harm to rangeland health } \\
2012 \text { drought severity } 11.10(4.45) \\
\text { Interaction of purchased feed/dry lot on drought severity } 0.24(0.14) \\
\text { Interaction of raising registered seed stock and drought severity } 60.08 \text { (95.58) }\end{array}$ & 346 & 63.15 & $<0.01$ & 825.10 & 0.07 \\
\hline $\begin{array}{l}\text { Harm to animal production } \\
2012 \text { drought severity } 3.40(1.27) \\
\text { Interaction of stockers/feeders and drought severity } 23.19 \text { (1.86) }\end{array}$ & 347 & 39.99 & $<0.01$ & 893.62 & 0.04 \\
\hline $\begin{array}{l}\text { Harm to cash flow } \\
2012 \text { drought severity } 5.49(1.25) \\
\text { Purchased hay } 2.18(0.46) \\
\text { Purchased feed/dry lot } 0.60(0.12)\end{array}$ & 337 & 66.40 & $<0.01$ & 833.72 & 0.07 \\
\hline $\begin{array}{l}\text { Harm to value of operation } \\
2012 \text { drought severity } 3.71(1.21) \\
\text { Interaction of shortgrass range (vs. mid-, mixed- or tallgrass range) and drought severity } 0.23 \text { ( } 0.17 \text { ) }\end{array}$ & 328 & 19.54 & $<0.01$ & 969.73 & 0.02 \\
\hline
\end{tabular}


Table 4

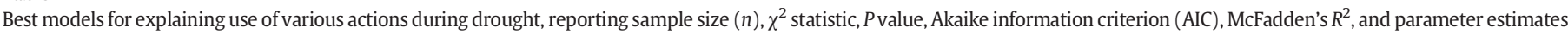
using odds ratios and standard errors in parenthesis. Intercepts are not shown.

\begin{tabular}{|c|c|c|c|c|c|}
\hline Action, odds ratio, and (standard error) & $n$ & $\chi^{2}$ & $P$ & AIC & $R^{2}$ \\
\hline \multicolumn{6}{|l|}{ Fed hay from own stockpiles } \\
\hline $\begin{array}{l}\text { Range/pasture and hay land } 8.73(2.80) \\
\text { Crop residue } 2.82(0.91)\end{array}$ & 414 & 53.56 & $<0.01$ & 287.90 & 0.16 \\
\hline \multicolumn{6}{|l|}{ Bought hay or feed to supplement } \\
\hline $\begin{array}{l}\text { Purchased hay } 10.83 \text { (3.47) } \\
2012 \text { drought severity } 3.79 \text { (1.43) }\end{array}$ & 345 & 93.71 & $<0.01$ & 441.17 & 0.19 \\
\hline \multicolumn{6}{|l|}{ Sold cull cows or feeder animals earlier than usual } \\
\hline $\begin{array}{l}2012 \text { drought severity } 3.41(1.12) \\
\text { Interaction of custom grazing and drought severity } 0.03(0.04) \\
\text { Interaction of having reserve forage and drought severity } 0.03(0.04)\end{array}$ & 328 & 36.47 & $<0.01$ & 400.50 & 0.09 \\
\hline \multicolumn{6}{|l|}{ Weaned calves earlier than usual } \\
\hline $\begin{array}{l}\text { PRF insurance } 1.96(0.50) \\
2012 \text { drought severity } 2.59(0.98) \\
\text { Interaction of shortgrass range and drought severity } 8.71 \text { (9.41) }\end{array}$ & 320 & 26.18 & $<0.01$ & 425.32 & 0.06 \\
\hline \multicolumn{6}{|l|}{ Grazed cover crop, residues, or alternative forage } \\
\hline $\begin{array}{l}\text { Crop residue } 8.96(2.17) \\
\text { Cover crops } 7.28(3.21)\end{array}$ & 412 & 152.05 & $<0.01$ & 423.20 & 0.27 \\
\hline \multicolumn{6}{|l|}{ Grazed fall or winter pastures earlier than planned } \\
\hline $\begin{array}{l}\text { Intensive early stocking } 2.58(0.81) \\
\text { Deferred rotation grazing } 1.72(0.40) \\
2012 \text { drought severity } 2.12(0.70)\end{array}$ & 324 & 21.74 & $<0.01$ & 435.31 & 0.05 \\
\hline $\begin{array}{l}\text { Reduced breeding animal numbers }(<25 \%) \\
2012 \text { drought severity } 2.14(0.69)\end{array}$ & 344 & 5.84 & 0.02 & 471.68 & 0.01 \\
\hline \multicolumn{6}{|l|}{ Reduced breeding animal numbers ( $>25 \%$ ) } \\
\hline $\begin{array}{l}2012 \text { drought severity } 20.94 \text { (15.67) } \\
\text { PRF insurance } 16.70 \text { (17.22) } \\
\text { Interaction of having PRF and drought severity } 0.08(0.08)\end{array}$ & 327 & 25.77 & $<0.01$ & 299.85 & 0.08 \\
\hline \multicolumn{6}{|l|}{ Leased/rented/purchased additional land to graze } \\
\hline \multicolumn{6}{|l|}{ Reduced stocker/yearling numbers $(<25 \%)$} \\
\hline Registered seed stock 3.43 (1.50) & 407 & 6.91 & 0.01 & 337.51 & 0.02 \\
\hline \multicolumn{6}{|l|}{ Reduced stocker/yearling numbers ( $>25 \%$ ) } \\
\hline $\begin{array}{l}\text { Stockers/feeders } 2.81 \text { (1.01) } \\
\text { Interaction of range/pasture/hay and drought severity } 40.25 \text { (69.86) }\end{array}$ & 335 & 15.89 & $<0.01$ & 231.51 & 0.08 \\
\hline \multicolumn{6}{|l|}{ Moved animals to feedlot } \\
\hline $\begin{array}{l}\text { Feedlot operation } 9.94 \text { (4.26) } \\
2012 \text { drought severity } 3.36 \text { (1.57) }\end{array}$ & 346 & 36.67 & $<0.01$ & 282.19 & 0.12 \\
\hline \multicolumn{6}{|l|}{ Sent custom grazed animals home early } \\
\hline Custom grazing 10.41 (3.57) & 407 & 44.39 & $<0.01$ & 270.65 & 0.14 \\
\hline
\end{tabular}

\section{Relationship Between Impacts and Response}

Correlations among impacts and response actions are shown in Index 1 (Part B). Actions involving destocking of livestock (i.e., early weaning culling, destocking breeders and/or stockers) were correlated with most types of impacts, as were buying hay, early grazing of fall/winter pastures, and leasing/renting/purchasing additional land to graze. Our results did not indicate a direction of causation, but considerations and recommendations for future research are discussed as follows.

\section{Discussion}

This study clarifies key relationships in the Chapin et al. (2009) model as related to rangeland management during drought, including the roles of the socioecological system and the drought hazard in predicting response and impact. With regard to impacts, drought severity plays the role of primary predictor, but the predictive ability of each model improves through the addition of socioecological characteristics measuring the sensitivity of the system. The specific mix of socioecological characteristics driving the system's sensitivity differs depending on the impact of interest (e.g., rangeland health versus cash flow). In other words, operations are not sensitive universally to all types of impacts, supporting Carpenter et al.'s (2001) call to assess resilience in relation to specific system configurations and disturbances. We also find that, in some cases, the effect of the socioecological system may be noticeable only at more severe levels of drought. This may be an indication of the particular system having reached a limit to the resilience of the system, before which multiple systems would respond similarly to disturbance.

The analysis highlights two distinct roles of the socioecological system in predicting drought response actions. In some cases, socioecological characteristics provide the resources or capacity that managers need to take action. These characteristics indicate the presence of adaptive capacity as described in both the climate vulnerability and socioecological resilience literatures (Walker and Abel, 2002; Yohe and Tol, 2002; Engle, 2011). But in other cases, the characteristics of the system predict the response action by signifying an increased need to take action, which may result from a lack of buffer or flexibility in the system. These findings highlight the need to examine the sensitivity of the system, as well as adaptive capacity, to explain adaptation decision making.

Characterizing actions according to whether they are driven by capacity or necessity adds to our understanding of distinctions between proactive and reactive decision making (Smit and Skinner, 2002) and the interconnected nature of hazard mitigation and response (Godschalk et al., 1998). Actions driven by necessity may be more likely to be reactive decisions and less likely to be part of a mitigation plan. They may be less preferable actions as well, from the manager's perspective. In recognition that all management decisions come with trade-offs (Walker et al., 2012), less preferred actions may lead the system to a less desirable state. It is worth exploring in future studies whether actions taken on a "need-to" basis are more likely to lead to negative transformation in the system, compared with those taken on an "able-to" basis. 
These findings help us interpret and understand the relationships between impacts and response. Whereas impacts and response actions were correlated in our analysis, causation was unclear and could, in some cases, be inferred in either direction. For example, the severity of harm to rangeland health was positively correlated with early weaning, early selling of culls, and large reductions in the breeding herd, likely because managers took these actions reactively to cope with the impact, not because the actions led to the impact. On the other hand, correlations between response actions and financial impacts may reflect causation in either (or both, or neither) direction, from response to impact or from impact to response. It is likely that in some cases, response actions may be associated with greater losses, in part based on the distinction among types of responses described earlier. Unfortunately, in this study we were unable to fully explore these relationships because the timing of the impact was not measured, and the timing of the response was measured only at an annual time-step. More fine-tuned measurement regarding the timing of response actions and impacts is necessary to more effectively examine these theoretical relationships.

To illustrate the effect of socioecological characteristics on managers' experiences of the 2012 drought, we describe a few scenarios. Respondents who raise stockers/feeders as part of their operation tended to have feedlot operations and/or have range/pasture/hay in their operations. Stocker/feeder operations with range/pasture/hay land were more likely than others to respond to severe drought with large reductions of their stocker/feeder numbers, likely because they had the stockers/feeders to sell but also because they were reliant on a feed base that was highly affected by the lack of precipitation. During the drought beginning in 2012, this group experienced the largest impacts to animal productivity.

Respondents with feedlot operations were more likely than others to rely on corn stalks and crop residue, purchased feed, and cover crops for their feed base. At any severity of drought, they were more likely than others to move animals to a feedlot. Those with cover crops were likely to graze them, and those with purchased feed were less likely than others to make large reductions to their stocker/feeder animals. Their tendency to rely on nonrange/ pasture resources for feed aligned with the fact that they were less likely than others to report severe harm to range health as drought severity increased.

Compared with other respondents, custom grazers were less likely to graze crop residue or purchase feed as part of their normal feed base and more likely to use intensive early grazing. They reacted to drought by sending custom grazing animals home early (at any level of drought) and, if using intensive early grazing, they grazed fall/winter pastures early in 2012. They were less likely than others to be impacted by severe forage feed reductions.

In summary, while $90 \%$ of the survey population for this study consisted of cow-calf operations, relatively minor differences among operations resulted in a diversity of drought management actions and impacts of the drought beginning in 2012. Operations differing from one another in terms of secondary enterprises, feed base, size, grazing system, and management approach experienced essentially different droughts at similar SPEI values. This underscores the importance of understanding the ways that the socioecological context shapes the system's sensitivity and adaptive capacity, in addition to the disturbance/ hazard context itself, in any discussion of drought preparedness and response.

\section{Opportunities for Future Research}

Although this study establishes a model for examining multiple facets of drought management, there are a few areas where future research could overcome our limitations in data or analysis. First, our decision to ask about tactical drought management actions using a predetermined list may have caused us to miss detecting other important tactical and/or strategic adaptive behaviors that managers implemented during the drought. Second, data limitations prevented us from including in this analysis either the predrought ecological condition of the rangeland or the stocking rate before or during drought. These are well-established (Teague et al., 2004) contextual factors that are likely to shape the options available to the manager during drought and also predict the impact of the drought on rangeland health, and they should be measured and included in future studies. Adding these variables to the predictive models is likely to improve their strength and may modify other relationships.

Third, societal factors such as conditions of livestock markets and land ownership patterns also shape and constrain manager decision making and are likely to strengthen the theoretical model, and they should be tested in future research. For example, the drought in question was geographically extensive and occurred in the context of record high feed costs, which likely limited opportunities from some adaptive measures such as movement of cattle and forage supplies (Adonizio et al., 2012). Finally, Chapin and colleagues' model does not address the psychological aspects of rangeland managers' decision-making processes, including their internalized expectations, norms, values, self-efficacy, or intentions, but these factors may also improve models predicting coping response. In short, there are numerous opportunities to build on this research to improve understanding of ranch decision making and drought management.

\section{Implications}

With regard to the question, "What can be done to better prepare rangeland managers for future drought events?" this study makes clear that "it depends" on the priorities of the manager and characteristics of the rangeland management system. Managers are likely to have preferences as to the types of impacts they most want to avoid, as well as drought response actions that are the most aligned with their management goals. Understanding the complex causal relationships of drought management should help managers to discern best practices for their unique situations and employ adaptive management that addresses the multifaceted, dynamic, adaptive socioecological systems they manage (Derner and Augustine, 2016). This framework should also help managers develop plans specific for drought management (Haigh and Knutson, 2013).

We've shown that adaptive management and planning processes should identify the socioecological factors that exacerbate or reduce an operation's sensitivity to critical impacts, as well as those factors that may be driving managers to take more or less desirable coping responses during drought. In addition, adaptation and planning processes should identify and work to develop the resources or capacity (e.g., feed, livestock, and financial resources) managers might need to respond to drought with their preferred actions. Studies like this one can support adaptive management and drought planning processes by depicting how various systems might function under droughts of different lengths or severities in the future. The benefit of such reflection is the ability to plan for proactive adaptation strategies that can lead to the persistence or positive transformation of rangeland socioecological systems in the face of future drought events.

\section{Acknowledgments}

The authors are grateful to Deborah Wood, National Drought Mitigation Center, for editing assistance, as well as to two anonymous reviewers whose questions and suggestions led to an improved final product. 


\section{Appendix 1}

Part A. Spearman rank correlations among independent variables, pairwise. (See below for variable codes.)

\begin{tabular}{|c|c|c|c|c|c|c|c|c|c|c|c|c|c|c|c|c|c|c|c|c|c|c|c|c|c|c|c|}
\hline & 1 & 2 & 3 & 6 & 7 & 8 & 9 & 10 & 11 & 12 & 13 & 14 & 15 & 16 & 17 & 18 & 19 & 20 & 21 & 22 & 23 & 24 & 25 & 26 & 27 & 28 & 29 \\
\hline 1 & 1.00 & $0.62^{*}$ & $0.17^{*}$ & $0.14^{*}$ & 0.10 & 0.00 & -0.02 & -0.01 & -0.03 & 0.05 & 0.04 & -0.08 & 0.11 & -0.04 & 0.09 & $-0.16^{*}$ & -0.05 & 0.00 & -0.04 & 0.05 & $-0.13^{*}$ & 0.03 & $0.13^{*}$ & $0.15^{*}$ & 0.04 & $0.20^{*}$ & -0.06 \\
\hline 2 & & 1.00 & $0.30^{*}$ & $0.12^{*}$ & $0.19^{*}$ & $-0.14^{*}$ & $0.16^{*}$ & -0.01 & -0.03 & 0.06 & -0.01 & -0.05 & $0.21^{*}$ & $-0.12^{*}$ & $0.18^{*}$ & $0.12^{*}$ & 0.09 & -0.03 & $0.12^{*}$ & $0.13^{*}$ & -0.08 & 0.06 & 0.07 & $0.15^{*}$ & 0.03 & $0.12^{*}$ & -0.09 \\
\hline 3 & & & 1.00 & 0.00 & 0.02 & -0.02 & 0.04 & -0.06 & -0.02 & -0.09 & 0.02 & 0.11 & $0.21^{*}$ & $-0.12^{*}$ & $0.16^{*}$ & 0.08 & 0.07 & -0.08 & $0.14^{*}$ & 0.08 & -0.07 & $0.11^{*}$ & -0.01 & -0.01 & -0.02 & 0.00 & -0.07 \\
\hline 4 & & & & 1.00 & 0.08 & -0.07 & -0.04 & 0.02 & 0.04 & 0.01 & 0.01 & -0.05 & 0.09 & -0.09 & 0.06 & -0.02 & $0.11^{*}$ & 0.09 & 0.09 & 0.01 & 0.12 & 0.03 & -0.09 & 0.09 & -0.02 & -0.07 & 0.00 \\
\hline 5 & & & & & 1.00 & -0.02 & $0.21^{*}$ & 0.03 & 0.00 & 0.03 & -0.05 & 0.01 & 0.03 & -0.09 & $0.10^{*}$ & -0.05 & 0.01 & 0.02 & -0.02 & 0.02 & 0.03 & 0.00 & 0.03 & 0.06 & 0.00 & 0.02 & -0.03 \\
\hline 6 & & & & & & 1.00 & 0.03 & 0.10 & -0.01 & -0.01 & 0.01 & 0.00 & 0.01 & 0.05 & -0.02 & $-0.20^{*}$ & -0.07 & -0.03 & $-0.14^{*}$ & 0.01 & -0.10 & 0.16 & 0.06 & -0.02 & 0.05 & 0.03 & 0.05 \\
\hline 7 & & & & & & & 1.00 & -0.02 & -0.06 & 0.02 & 0.08 & -0.05 & $0.11^{*}$ & -0.02 & 0.05 & $0.16^{*}$ & $0.13^{*}$ & -0.02 & $0.14^{*}$ & 0.05 & 0.00 & 0.06 & 0.04 & 0.01 & 0.06 & -0.04 & 0.06 \\
\hline 8 & & & & & & & & 1.00 & -0.03 & 0.00 & 0.00 & 0.03 & 0.07 & $-0.16^{*}$ & $0.15^{*}$ & 0.02 & -0.09 & $-0.22^{*}$ & -0.09 & 0.01 & 0.05 & 0.02 & -0.02 & 0.02 & 0.07 & -0.09 & -0.04 \\
\hline 9 & & & & & & & & & 1.00 & $-0.34^{*}$ & $-0.12^{*}$ & $-0.15^{*}$ & -0.06 & -0.03 & 0.05 & -0.05 & -0.05 & 0.05 & 0.04 & -0.08 & 0.03 & 0.02 & 0.02 & 0.04 & 0.01 & -0.02 & 0.00 \\
\hline 10 & & & & & & & & & & 1.00 & $-0.47^{*}$ & $-0.59^{*}$ & $0.10^{*}$ & 0.06 & -0.03 & 0.00 & 0.03 & -0.03 & -0.01 & 0.01 & $-0.11^{*}$ & -0.03 & 0.03 & -0.01 & -0.01 & -0.03 & $0.21^{*}$ \\
\hline 11 & & & & & & & & & & & 1.00 & $-0.21^{*}$ & -0.05 & 0.08 & -0.08 & -0.01 & -0.02 & 0.10 & 0.02 & 0.02 & 0.06 & $-0.11^{*}$ & -0.06 & $-0.11^{*}$ & -0.07 & -0.04 & -0.10 \\
\hline 12 & & & & & & & & & & & & 1.00 & -0.04 & $-0.12^{*}$ & 0.08 & 0.05 & 0.01 & -0.08 & -0.03 & 0.03 & 0.07 & $0.12^{*}$ & 0.00 & 0.07 & 0.07 & 0.08 & $-0.17^{*}$ \\
\hline 13 & & & & & & & & & & & & & 1.00 & -0.05 & 0.06 & $0.24^{*}$ & $0.24^{*}$ & -0.05 & -0.02 & -0.03 & -0.03 & 0.07 & -0.03 & 0.09 & 0.05 & 0.01 & $0.33^{*}$ \\
\hline 14 & & & & & & & & & & & & & & 1.00 & $-0.79 *$ & 0.02 & -0.03 & $0.24^{*}$ & 0.09 & $-0.13^{*}$ & -0.01 & 0.01 & -0.01 & -0.01 & 0.03 & -0.10 & $0.16^{*}$ \\
\hline 15 & & & & & & & & & & & & & & & 1.00 & -0.07 & 0.03 & $-0.19^{*}$ & 0.04 & $0.11^{*}$ & -0.03 & 0.06 & 0.05 & 0.05 & 0.01 & 0.08 & $-0.18^{*}$ \\
\hline 16 & & & & & & & & & & & & & & & & 1.00 & $0.29^{*}$ & $0.13^{*}$ & 0.08 & 0.03 & $0.15^{*}$ & -0.09 & -0.04 & 0.00 & -0.02 & 0.00 & $0.12^{*}$ \\
\hline 17 & & & & & & & & & & & & & & & & & 1.00 & 0.09 & 0.09 & $-0.11^{*}$ & 0.01 & 0.03 & 0.01 & 0.06 & 0.03 & -0.04 & 0.08 \\
\hline 18 & & & & & & & & & & & & & & & & & & 1.00 & $0.26^{*}$ & $-0.17^{*}$ & $0.11^{*}$ & -0.05 & 0.05 & 0.02 & $-0.11^{*}$ & 0.00 & $0.13^{*}$ \\
\hline 19 & & & & & & & & & & & & & & & & & & & 1.00 & -0.02 & 0.01 & 0.04 & 0.02 & -0.03 & -0.02 & 0.01 & -0.02 \\
\hline 20 & & & & & & & & & & & & & & & & & & & & 1.00 & -0.08 & 0.02 & -0.04 & 0.07 & 0.00 & 0.08 & -0.05 \\
\hline 21 & & & & & & & & & & & & & & & & & & & & & 1.00 & -0.06 & $-0.22^{*}$ & $-0.14^{*}$ & -0.09 & -0.09 & -0.02 \\
\hline 22 & & & & & & & & & & & & & & & & & & & & & & 1.00 & $0.15^{*}$ & $0.12^{*}$ & $0.21^{*}$ & -0.02 & 0.02 \\
\hline 23 & & & & & & & & & & & & & & & & & & & & & & & 1.00 & 0.00 & -0.07 & 0.03 & -0.04 \\
\hline 24 & & & & & & & & & & & & & & & & & & & & & & & & 1.00 & 0.08 & $0.13^{*}$ & 0.01 \\
\hline 25 & & & & & & & & & & & & & & & & & & & & & & & & & 1.00 & 0.00 & 0.04 \\
\hline 26 & & & & & & & & & & & & & & & & & & & & & & & & & & 1.00 & -0.09 \\
\hline 27 & & & & & & & & & & & & & & & & & & & & & & & & & & & 1.00 \\
\hline
\end{tabular}


Part B: Spearman rank correlations among independent and dependent variables, pairwise. (See below for variable codes.)

\begin{tabular}{|c|c|c|c|c|c|c|c|c|c|c|c|c|c|c|c|c|c|c|}
\hline & 28 & 29 & 30 & 31 & 32 & 33 & 34 & 35 & 36 & 37 & 38 & 39 & 40 & 41 & 42 & 43 & 44 & 45 \\
\hline 1 & 0.11 & -0.04 & 0.00 & -0.03 & -0.04 & 0.05 & 0.03 & 0.11 & -0.10 & 0.08 & -0.03 & 0.09 & $0.18^{*}$ & $0.18^{*}$ & 0.09 & 0.01 & 0.02 & $0.17^{*}$ \\
\hline 2 & 0.01 & -0.08 & $-0.14^{*}$ & $-0.12^{*}$ & $-0.13^{*}$ & -0.03 & $0.21^{*}$ & 0.00 & -0.01 & $0.14^{*}$ & $-0.12^{*}$ & 0.10 & $0.16^{*}$ & 0.09 & 0.01 & -0.08 & 0.02 & 0.04 \\
\hline 3 & -0.06 & -0.06 & -0.02 & -0.07 & -0.07 & -0.04 & $0.19^{*}$ & 0.09 & 0.07 & 0.01 & 0.00 & -0.01 & 0.09 & $0.13^{*}$ & -0.02 & -0.05 & -0.05 & 0.03 \\
\hline 4 & -0.04 & 0.04 & 0.05 & 0.09 & 0.01 & 0.07 & 0.07 & 0.02 & -0.04 & 0.04 & $-0.10^{*}$ & 0.09 & 0.07 & 0.05 & 0.05 & -0.04 & $0.15^{*}$ & -0.07 \\
\hline 5 & -0.06 & -0.04 & $0.13^{*}$ & 0.00 & -0.09 & -0.04 & 0.04 & -0.04 & 0.02 & $0.10^{*}$ & -0.07 & -0.01 & 0.06 & 0.07 & -0.02 & 0.07 & 0.08 & $0.19^{*}$ \\
\hline 6 & -0.07 & 0.00 & 0.04 & 0.02 & 0.04 & -0.04 & $-0.24^{*}$ & 0.01 & -0.06 & -0.07 & $0.39^{*}$ & -0.04 & -0.04 & $-0.10^{*}$ & $-0.10^{*}$ & 0.00 & -0.04 & 0.01 \\
\hline 7 & -0.03 & -0.03 & 0.00 & -0.02 & -0.06 & -0.04 & 0.00 & 0.00 & 0.11 & 0.35 & 0.02 & 0.05 & 0.03 & -0.05 & -0.06 & 0.05 & 0.05 & 0.00 \\
\hline 8 & $-0.13^{*}$ & $-0.15^{*}$ & $-0.15^{*}$ & $-0.12^{*}$ & -0.08 & $-0.17^{*}$ & 0.08 & -0.07 & -0.03 & 0.00 & 0.03 & -0.06 & -0.10 & -0.08 & -0.01 & -0.07 & 0.03 & -0.03 \\
\hline 9 & 0.00 & 0.00 & 0.04 & 0.06 & 0.06 & 0.03 & -0.09 & 0.02 & -0.01 & 0.01 & 0.02 & 0.01 & -0.04 & -0.04 & 0.05 & -0.02 & -0.07 & 0.03 \\
\hline 10 & 0.10 & $0.12^{*}$ & 0.03 & 0.09 & $0.11^{*}$ & 0.05 & $0.11^{*}$ & 0.03 & 0.00 & 0.02 & 0.03 & 0.04 & 0.07 & 0.09 & 0.00 & 0.07 & 0.09 & -0.08 \\
\hline 11 & 0.05 & -0.09 & -0.07 & -0.06 & -0.06 & -0.03 & $-0.11^{*}$ & -0.07 & 0.01 & 0.03 & -0.03 & -0.03 & -0.05 & -0.09 & 0.01 & 0.00 & -0.01 & 0.04 \\
\hline 12 & $-0.16^{*}$ & -0.08 & 0.00 & -0.10 & $-0.12^{*}$ & -0.06 & 0.02 & 0.01 & 0.01 & -0.06 & -0.03 & -0.03 & -0.01 & 0.00 & -0.04 & -0.06 & -0.06 & 0.04 \\
\hline 13 & 0.07 & $0.20^{*}$ & $0.18^{*}$ & $0.16^{*}$ & $0.10^{*}$ & 0.03 & $0.17^{*}$ & 0.08 & $0.26^{*}$ & $0.11^{*}$ & 0.02 & 0.01 & $0.17^{*}$ & 0.07 & 0.02 & 0.06 & 0.08 & $0.13^{*}$ \\
\hline 14 & 0.09 & 0.05 & 0.04 & 0.08 & 0.02 & 0.08 & $-0.32^{*}$ & -0.04 & 0.03 & 0.00 & 0.08 & -0.04 & 0.02 & -0.08 & -0.04 & 0.08 & -0.01 & -0.09 \\
\hline 15 & -0.01 & -0.09 & -0.05 & $-0.10^{*}$ & -0.07 & -0.06 & $0.35^{*}$ & $0.10^{*}$ & -0.05 & 0.04 & -0.05 & 0.04 & 0.02 & 0.08 & 0.04 & -0.05 & 0.05 & 0.09 \\
\hline 16 & 0.05 & 0.12 & 0.02 & 0.02 & -0.01 & 0.01 & 0.12 & -0.07 & $0.54^{*}$ & $0.14^{*}$ & -0.05 & 0.02 & $0.16^{*}$ & -0.03 & 0.09 & -0.04 & 0.02 & -0.03 \\
\hline 17 & 0.06 & 0.07 & $0.10^{*}$ & $0.15^{*}$ & 0.00 & 0.00 & 0.06 & 0.00 & $0.35^{*}$ & $0.11^{*}$ & 0.00 & 0.03 & 0.05 & 0.00 & -0.04 & 0.10 & 0.06 & 0.02 \\
\hline 18 & $0.15^{*}$ & $0.10^{*}$ & $0.14^{*}$ & $0.20^{*}$ & 0.01 & $0.47^{*}$ & $-0.13^{*}$ & -0.03 & 0.06 & $0.11^{*}$ & 0.05 & 0.01 & 0.07 & 0.08 & 0.06 & 0.08 & 0.05 & 0.07 \\
\hline 19 & $0.11^{*}$ & $-0.11^{*}$ & $-0.14^{*}$ & -0.07 & $-0.12^{*}$ & $0.17^{*}$ & 0.05 & 0.04 & 0.04 & $0.15^{*}$ & -0.04 & 0.09 & 0.04 & 0.00 & -0.04 & 0.06 & 0.01 & 0.04 \\
\hline 20 & -0.01 & 0.02 & 0.01 & -0.01 & -0.08 & $-0.11^{*}$ & $0.17^{*}$ & -0.01 & -0.08 & 0.05 & -0.03 & 0.07 & 0.05 & 0.08 & 0.03 & 0.03 & 0.07 & 0.09 \\
\hline 21 & -0.10 & -0.02 & -0.03 & -0.02 & -0.03 & 0.06 & 0.06 & $-0.16^{*}$ & 0.03 & -0.01 & -0.08 & 0.02 & -0.07 & $-0.13^{*}$ & -0.05 & $-0.11^{*}$ & -0.10 & -0.09 \\
\hline 22 & 0.06 & -0.01 & 0.04 & -0.02 & -0.02 & 0.06 & 0.04 & $0.18^{*}$ & -0.06 & 0.00 & $0.19^{*}$ & 0.00 & 0.02 & 0.05 & 0.00 & 0.03 & 0.01 & -0.03 \\
\hline 23 & 0.06 & -0.07 & 0.01 & -0.06 & 0.03 & 0.07 & -0.02 & $0.17^{*}$ & 0.01 & 0.07 & 0.00 & -0.04 & 0.07 & 0.06 & 0.05 & 0.09 & 0.02 & $0.14^{*}$ \\
\hline 24 & $0.11^{*}$ & 0.08 & 0.10 & 0.08 & -0.01 & -0.02 & -0.02 & 0.01 & -0.01 & 0.09 & 0.02 & 0.01 & $0.11^{*}$ & $0.12^{*}$ & 0.09 & 0.07 & 0.07 & 0.07 \\
\hline 25 & 0.01 & 0.05 & 0.02 & -0.05 & 0.02 & -0.06 & 0.04 & 0.05 & -0.03 & 0.04 & 0.05 & 0.04 & -0.02 & 0.06 & 0.03 & -0.02 & 0.02 & 0.00 \\
\hline 26 & 0.08 & 0.08 & 0.04 & 0.07 & 0.01 & 0.01 & -0.01 & 0.03 & 0.05 & 0.01 & -0.01 & $0.10^{*}$ & $0.14^{*}$ & $0.12^{*}$ & 0.09 & 0.03 & -0.04 & $0.20^{*}$ \\
\hline 27 & $0.22^{*}$ & $0.36^{*}$ & $0.29^{*}$ & $0.35^{*}$ & $0.20^{*}$ & $0.23^{*}$ & -0.06 & $0.11^{*}$ & $0.11^{*}$ & $0.17^{*}$ & 0.09 & 0.07 & $0.22^{*}$ & $0.19^{*}$ & 0.11 & $0.25^{*}$ & 0.03 & 0.01 \\
\hline 28 & 1.00 & $0.19^{*}$ & $0.11^{*}$ & $0.25^{*}$ & $0.13^{*}$ & $0.18^{*}$ & 0.08 & $0.13^{*}$ & 0.06 & $0.14^{*}$ & 0.05 & 0.03 & $0.18^{*}$ & $0.19^{*}$ & 0.10 & $0.19^{*}$ & 0.05 & 0.10 \\
\hline 29 & & 1.00 & $0.51^{*}$ & $0.48^{*}$ & $0.43^{*}$ & $0.16^{*}$ & 0.00 & $0.13^{*}$ & 0.09 & $0.10^{*}$ & 0.07 & $0.11^{*}$ & $0.30^{*}$ & $0.28^{*}$ & $0.18^{*}$ & $0.27^{*}$ & $0.13^{*}$ & $0.12^{*}$ \\
\hline 30 & & & 1.00 & $0.58^{*}$ & $0.44^{*}$ & $0.21^{*}$ & -0.04 & $0.19^{*}$ & $0.14^{*}$ & 0.09 & 0.07 & 0.09 & $0.28^{*}$ & $0.28^{*}$ & $0.14^{*}$ & $0.39^{*}$ & $0.19^{*}$ & $0.30^{*}$ \\
\hline 31 & & & & 1.00 & $0.43^{*}$ & $0.29^{*}$ & -0.02 & $0.19^{*}$ & $0.12^{*}$ & $0.10^{*}$ & 0.06 & $0.21^{*}$ & $0.30^{*}$ & $0.32^{*}$ & $0.19^{*}$ & $0.35^{*}$ & $0.13^{*}$ & $0.25^{*}$ \\
\hline 32 & & & & & 1.00 & $0.15^{*}$ & -0.01 & $0.25^{*}$ & 0.02 & 0.03 & $0.15^{*}$ & $0.13^{*}$ & $0.20^{*}$ & $0.21^{*}$ & 0.09 & $0.24^{*}$ & $0.13^{*}$ & $0.17^{*}$ \\
\hline 33 & & & & & & 1.00 & 0.03 & $0.19^{*}$ & 0.08 & $0.14^{*}$ & 0.02 & $0.11^{*}$ & $0.21^{*}$ & $0.25^{*}$ & $0.16^{*}$ & $0.13^{*}$ & $0.17^{*}$ & $0.13^{*}$ \\
\hline 34 & & & & & & & 1.00 & $0.14^{*}$ & $0.16^{*}$ & 0.03 & $-0.13^{*}$ & 0.05 & $0.14^{*}$ & $0.15^{*}$ & 0.08 & -0.03 & 0.02 & 0.07 \\
\hline 35 & & & & & & & & 1.00 & 0.09 & $0.11^{*}$ & 0.03 & $0.16^{*}$ & $0.31^{*}$ & $0.32^{*}$ & $0.12^{*}$ & $0.14^{*}$ & 0.08 & $0.14^{*}$ \\
\hline 36 & & & & & & & & & 1.00 & 0.10 & -0.03 & $0.10^{*}$ & $0.15^{*}$ & 0.07 & 0.04 & 0.10 & 0.03 & 0.08 \\
\hline 37 & & & & & & & & & & 1.00 & 0.05 & 0.07 & $0.27^{*}$ & $0.14^{*}$ & 0.05 & $0.11^{*}$ & $0.13^{*}$ & 0.05 \\
\hline 38 & & & & & & & & & & & 1.00 & 0.00 & 0.07 & 0.05 & 0.01 & 0.00 & -0.03 & 0.07 \\
\hline 39 & & & & & & & & & & & & 1.00 & $0.17^{*}$ & $0.14^{*}$ & 0.07 & $0.13^{*}$ & 0.00 & 0.08 \\
\hline 40 & & & & & & & & & & & & & 1.00 & $0.43^{*}$ & $0.24^{*}$ & $0.25^{*}$ & $0.16^{*}$ & $0.18^{*}$ \\
\hline 41 & & & & & & & & & & & & & & 1.00 & $0.35^{*}$ & $0.20^{*}$ & $0.18^{*}$ & $0.24^{*}$ \\
\hline 42 & & & & & & & & & & & & & & & 1.00 & $-0.12^{*}$ & $0.25^{*}$ & 0.03 \\
\hline 43 & & & & & & & & & & & & & & & & 1.00 & 0.07 & $0.40^{*}$ \\
\hline 44 & & & & & & & & & & & & & & & & & 1.00 & $0.12^{*}$ \\
\hline 45 & & & & & & & & & & & & & & & & & & 1.00 \\
\hline
\end{tabular}


* $\quad$ Correlation significant at $P<0.05$

$n$ for each correlation varies, dependent on the variable $n$. See Tables 1 and 2 for variable $n$

1 Number of hectares of permanent pasture and range, woodland pasture, and cropland used for pasture

2 Number of beef cows/heifers/steers/calves/bulls 2012

3 Percent of household income from operation

4 Raises registered seed stock

5 Raises stockers/feeder calves

6 Custom grazes (cattle run on ranch but not owned)

7 Has feedlot

8 Hay/forage production to sell

9 Majority of pastures/rangeland native tall grass

10 Majority of pastures/rangeland native mixed grass

11 Majority of pastures/rangeland native short grass

12 Majority of pastures/rangeland mix of native/introduced grasses

13 Manages irrigated crop/hay land or subirrigated meadows

14 Feed base includes range/pasture, no hay land

15 Feed base includes range/pasture and hay land

16 Feed base includes corn stalks or other crop residue

17 Feed base includes cover crops

18 Feed base includes purchased hay

19 Feed base includes purchased feed/dry lot

20 Typically keeps forage in reserve in nondrought years

21 Currently uses season-long continuous grazing

22 Currently uses intensive early stocking

23 Currently uses deferred rotation grazing

24 Currently uses rest rotation grazing

25 Currently uses intensively managed rotation grazing

26 Pasture, Range, and Forage Insurance between 2012 and 2014

27 Median SPEI value for 2012 (reverse)

28 Percent forage feed reduction

29 Perceived effect of drought on rangeland health

30 Perc. effect of drought on animal production

31 Perc. effect of drought on cash reserves or savings

32 Perc. effect of drought on value of ranch operation

33 Bought hay/feed to supplement in 2012

34 Fed hay from own stockpiles in 2012

35 Grazed fall/winter pastures earlier than planned 2012

36 Grazed cover crop, crop residues, or alternative forages 2012

37 Moved animals to feedlot in 2012 because of drought

38 Sent custom-grazed animals home early in 2012

39 Leased/rented/purchased additional land to graze in 2012

40 Weaned calves earlier than usual in 2012

41 Sold cull cows or feeder animals earlier than usual in 2012

42 Reduced breeding animal numbers (by $\leq 25 \%$ ) in 2012

43 Reduced breeding animal numbers (by $>25 \%$ ) 2012

44 Reduced stocker/yearling numbers (by $\leq 25 \%$ ) in 2012

45 Reduced stocker/yearling numbers (by $>25 \%$ ) 2012

\section{References}

Adger, W.N., Brooks, N., Bentham, G., Agnew, M., Eriksen, S., 2004. New indicators of vulnerability and adaptive capacity. Tyndall Centre for Climate Change Research, Sussex, United Kingdom 128 pp.

Adonizio, W., Kook, N., Royales, S., 2012. Impact of the drought on corn exports: paying the price. Beyond the Numbers: Global Economy, volume 1, no. 17 Bureau of Labor Statistics, November. Available at:. http://www.bls.gov/opub/btn/volume-1/impactof-the-drought-on-corn-exportspaying-the-price.htm, Accessed date: 2 February 2019.

Bastian, C.T., Mooney, S., Nagler, A.M., Hewlett, J.P., Paisley, S.I., Smith, M.A., Frasier, W.M., Umberger, W.J., 2006. Rangers diverse in their drought management strategies. Western Economics Forum 2, 1-8.

Birge, H.E., 2017. Soil ecosystem service tradeoffs and social-ecological resilience in the North Central Great Plains. [dissertation]. The University of Nebraska, Lincoln, NE, USA $231 \mathrm{pp}$.

Briske, D.D., Derner, J.D., Brown, J.R., Fuhlendorf, S.D., Teague, W.R., Havstad, K.M., Gillen, R.L., Ash, A.J., Willms, W.D., 2008. Rotational grazing on rangelands: reconciliation of perception and experimental evidence. Rangeland Ecology \& Management 61, 3-17.

Brooks, N., 2003. Vulnerability, risk and adaptation: a conceptual framework. Tyndall Centre for Climate Change Research Working Paper 38, pp. 1-16.

Carpenter, S., Walker, B., Anderies, J.M., Abel, N., 2001. From metaphor to measurement: resilience of what to what? Ecosystems 4, 765-781.

Chapin, F.S., Folke, C., Kofinas, G.P., 2009. A framework for understanding change. In: Capin, F.S., Folke, C., Kofinas, G.P. (Eds.), Principles of ecosystem stewardship: resil- ience-based natural resource management in a changing world. Springer, New York, NY, USA , pp. 3-28 Available at:. https://doi.org/10.1007/978-0-387-73033-2 1. Coppock, L, 2011. Ranching and multiyear droughts in Utah: production impacts, risk perceptions, and changes in preparedness. Rangeland Ecology \& Management 64, 607-618.

Derner, J.D., Augustine, D.J., 2016. Adaptive management for drought on rangelands. Rangelands 38, 211-215.

Dunn, B., Smart, A.J., Gates, R., 2005. Barriers to successful drought management: why do some ranchers fail to take action? Rangelands 27, 13-16.

Eakin, H., Bojórquez-Tapia, L.A., 2008. Insights into the composition of household vulnerability from multicriteria decision analysis. Global Environmental Change 18, 112-127 Available at: https://doi.org/10.1016/j.gloenvcha.2007.09.001. Accessed.

Engle, N.L., 2011. Adaptive capacity and its assessment. Global Environmental Change 21, 647-656 Available at: https://doi.org/10.1016/j.gloenvcha.2011.01.019.

Feola, G., Binder, C.R., 2010. Towards an improved understanding of farmers' behaviour: the integrative agent-centred (IAC) framework. Ecological Economics 69, 2323-2333 Available at: https://doi.org/10.1016/j.ecolecon.2010.07.023. Accessed....

Folke, C., Carpenter, S., Elmqvist, T., Gunderson, L., Holling, C.S., Walker, B., 2002. Resilience and sustainable development: building adaptive capacity in a world of transformations. Ambio 31, 437-440 Available at: https://doi.org/citeulike-article-id: 1524120. Accessed....

Godschalk, D., Beatley, T., Berke, P., Brower, D., Kaiser, E.J., 1998. Natural hazard mitigation: recasting disaster policy and planning. Island Press, Washington, DC, USA $591 \mathrm{pp}$.

Haigh, T., Knutson, C.L., 2013. Roles of perceived control and planning in ranch drought preparedness. Great Plains Research 23, 51-58.

Hosmer Jr., D.W., Lemeshow, S., Sturdivant, R.X., 2000. Applied logistic regression. Volume 398. John Wiley \& Sons, Hoboken, NJ, USA 500 pp.

Kachergis, E., Derner, J.D., Cutts, B.B., Roche, L.M., Eviner, V.T., Lubell, M.N., Tate, K.W., 2014. Increasing flexibility in rangeland management during drought. Ecosphere 5, 1-14

Knutson, C., Haigh, T., 2013. A drought-planning methodology for ranchers in the Great Plains. Rangelands 35, 27-33.

McFadden, D., 1974. Conditional logit analysis of qualitative choice behavior. In: Zarembka, P. (Ed.), Frontiers in econometrics. Academic Press, New York, NY, USA pp. 105-142 Available at:. http://eml.berkeley.edu/ mcfadden/travel.html, Accessed date: 2 February 2019.

Miller, F., Osbahr, H., Boyd, E., Thomalla, F., Bharwani, S., Ziervogel, G., Walker, B., Birkmann, J., van der Leeuw, S., Rockström, J., Hinkel, J., Downing, T., Folke, C. Nelson, D., 2010. Resilience and vulnerability: complementary or conflicting concepts? Ecology and Society 15 Available at: https://doi.org/10.5751/ES-03378150311.

NDMC (National Drought Mitigation Center), 2017. Drought risk atlas. Available at:. http: droughtatlas.unl.edu, Accessed date: 2 February 2019

NOAA-NCEI (National Centers for Environmental Information), 2012. National Climate Report-Annual 2012. Available at:. https://www.ncdc.noaa.gov/sotc/national/201213.

Smit, B., Skinner, M.W., 2002. Adaptation options in agriculture to climate change: a typology. Mitigation and Adaptation Strategies for Global Change 7, 85-114 Available at: https://doi.org/10.1023/A:1015862228270. Accessed....

StataCorp [computer program], 2009. Stata Statistical Software: Release 11. StataCorp LP College Station, TX, USA

Stockton, M.C., Dhoubhadel, S.P., 2011. A good drought plan may save your ranch and improve your bottom line. Cornhusker Economics. Paper 490 Available at:. http:// digitalcommons.unl.edu/agecon cornhusker/490, Accessed date: 2 February 2019.

Svoboda, M., Fuchs, B.A., 2016. Handbook of drought indicators and indices. Integrated Drought Management Programme (IDMP), Integrated Drought Management Tools and Guidelines Series 2. World Meteorological Organization and Global Water Partnership, Geneva, Switzerland 52 pp Available at:. http:drought.unl.edu, Accessed date: 2 February 2019.

Teague, W.R., Dowhower, S.L., Waggoneer, J.A., 2004. Drought and grazing patch dynamics under different grazing management. Journal of Arid Environments 58, 97-117.

Thurow, T.L., Taylor Jr., C.A., 1999. Viewpoint: the role of drought in range management. Journal of Range Management 52, 413-419.

USDA NASS (US Department of Agriculture National Agricultural Statistics Service), 2012 Census highlights. Available at:. https://www.agcensus.usda.gov/Publications/2012/ Online_Resources/Highlights/Farm_Demographics/\#average_age, Accessed date: 2 February 2019.

USDA NRCS (US Department of Agriculture Natural Resources Conservation Service), 2006. Land resource regions and major land resource areas of the United States, the Caribbean, and the Pacific Basin. US Department of Agriculture Handbook 296, Washington, DC, USA $682 \mathrm{pp}$.

Vandeveer, M., Berger, A., Stockton, M., 2013. Pasture, rangeland and forage insurance for Nebraskans: an insurance pilot program to protect livestock and hay producers. Cornhusker Economics 653 Available at:. http://digitalcommons.unl.edu/agecon cornhusker/653, Accessed date: 2 February 2019

Walker, B.H., Abel, N.O.J., 2002. Resilient rangelands-adaptation in complex systems. In: Gunderson, L.H., Holling, C.S. (Eds.), Panarchy: understanding transformations in human and natural systems. Island Press, Washington, DC, USA, pp. 293-313.

Walker, B.H., Carpenter, S.R., Rockstrom, J., Peterson, G.D., 2012. Drivers, "slow" variables, "fast" variables, shocks, and resilience. Ecology \& Society 17, 1-4.

Wilhelmi, O.V., Wilhite, D.A., 2002. Assessing vulnerability to agricultural drought: a Nebraska case study. Natural Hazards 25, 37-58.

Wilhite, D.A., 2000. Drought as a natural hazard: concepts and definitions. In: Wilhite, D.A. (Ed.), Drought: a global assessment. Volume 1. Routledge, London, England, pp. 3-18.

Yohe, G., Tol, R.S., 2002. Indicators for social and economic coping capacity-moving toward a working definition of adaptive capacity. Global Environmental Change 12, 25-40. 